\title{
Penggunaan Partikel Sae, Shika, dan Dake dalam Novel Botchan Karya Natsume Soseki
}

\author{
I Made Adi Suardika \\ Program Studi Sastra Jepang Fakultas Ilmu Budaya \\ [madeadi383@gmail.com]
}

\begin{abstract}
This research entitled "Use of particles sae, shika and dake in Botchan's Novel by Natsume Soseki". The theories used for analyzing are syntax theory by Nitta (1997), theory of fungtions by Sunagawa (1991), and contextual meaning theory by Chaer (2007). Based on the analysis that has been done, there are two forms of sae, three forms of shika, and four forms of dake. For the funtions and meanings of sae are reinforces a part, indicates terms, and shows unconditionally. The funtions and meanings of shika show the smallest amount, the limits of action, and emphasize one thing only. The funtions and meanings of dake shows limitations, levels, habits, and affirmation of another.
\end{abstract}

Keywords: particle sae, particle shika, particle dake, forms, funtions, meanings

\begin{abstract}
Abstrak
Penelitian ini berjudul "Penggunaan Partikel Sae, Shika, dan Dake dalam Novel Botchan Karya Natsume Soseki". Teori yang digunakan dalam penelitian ini adalah teori sintaksis yang dikemukakan oleh Nitta (1997), teori fungsi dari Sunagawa (1991) dan teori makna kontekstual dari Chaer (2007). Bentuk partikel sae terdiri dari dua bentuk utama, bentuk partikel shika terdiri dari tiga bentuk, sedangkan bentuk partikel dake terdiri dari empat buah. Fungsi dan makna partikel sae adalah untuk mempertegas suatu bagian, menunjukkan syarat, dan menunjukkan tanpa syarat. Fungsi dan makna partikel shika adalah untuk menunjukikan jumlah terkecil, menunjukkan batasan perbuatan, dan menekankan satu hal saja. Fungsi dan makna partikel dake adalah menunjukkan batasan, tingkatan, kebiasaan, dan penegasan suatu yang lain.
\end{abstract}

Kata kunci : partikel sae, partikel shika, partikel dake, bentuk, fungsi, makna

\section{Latar Belakang}

Partikel dalam bahasa Jepang disebut juga dengan istilah joshi. Menurut Sudjianto dan Dahidi (2007:181), joshi merupakan kelas kata yang termasuk Fuzokugo ( 付属語) ( jenis kata yang tidak dapat berdiri sendiri) yang dipakai setelah suatu kata untuk menunjukkan hubungan antara kata tersebut dengan kata lain serta untuk menambah arti kata tersebut agar lebih jelas. Partikel berfungsi sebagai penghubung antara kata dengan kata lain serta untuk menambah makna kata tersebut agar lebih jelas, partikel hampir selalu muncul dalam kalimat bahasa Jepang. Salah satu partikel yang sering muncul dalam kalimat bahasa Jepang adalah partikel sae, shika dan dake. Partikel sae, shika dan dake memiliki fungsi dan makna yang 
berbeda-beda sesuai dengan kata yang dihubungkannya dalam kalimat.

Contoh dalam kalimat adalah sebagai berikut :

\section{Partikel sae}

$\begin{array}{lll}\text { 1) 自分 の } & \text { 名前 } & \text { さ } \\ \text { え } & & \\ \text { Jibun no namae } & \underline{\text { sae }} \\ \text { Sendiri Gen nama } & \underline{\text { Part }} \\ \text { 書けない。 } & & \\ \text { kakenai. } & & \\ \text { tidak bisa menulis } & & \\ \text { 'Namanya sendiripun tidak } & \text { bisa } \\ \text { menulis' } & & \end{array}$

(Sudjianto, 2000:31)

Fungsi partikel sae pada kalimat 1) tersebut adalah untuk menyatakan standar, ukuran, atau batas-batas terendah suatu keadaan/aktivitas, dan berfungsi menunjuk-kan salah satu perumpamaan.

\section{Partikel shika}

2) 男

$$
\text { の子は 四人 }
$$

Otoko no ko wa yo-nin Laki-laki Gen anak TOP 4 orang

$\frac{\text { しか }}{\underline{\text { shika }}} \begin{gathered}\text { imasen. } \\ \text { Part }\end{gathered}$ tidak ada

'Tidak ada hanya 4 orang anak lakilaki'

(Sudjianto, 2000: 32)

Partikel shika sering dipakai setelah nomina atau setelah verba bentuk kamus. Namun dapat dipakai juga setelah partikel lain dan setelah adverbial (misalnya adverbial tamani). Fungsi partikel shika pada kalimat b. tersebut adalah untuk menegaskan adanya keterbatasan (jumlah) suatu benda, aktivitas atau keadaan.

\section{Partikel dake}

3) みんな

出かけて、 わたし

Minna dekakete, watashi

Semua sedang keluar saya

だけ家ににます。

dake uchi ni imasu.

$\underline{\text { Part rumah DAT ada }}$

'Semuanya sedang keluar, yang dirumah hanya saya'

(Sugihartono, 2001: 122)

Fungsi partikel dake pada kalimat 3) tersebut adalah menunjukkan arti batasan "hanya" atau "selain itu tak ada".

Berdasarkan data tersebut, diketahui bahwa tiga contoh kalimat tersebut samasama memakai partikel sae, shika dan dake, yang memiliki arti "hanya", namun mempunyai fungsi yang berbeda. Kalimat 1) menyatakan standar, ukuran, atau batas-batas terendah suatu keadaan. Kalimat 2) menyatakan adanya keterbatasan (jumlah) suatu benda atau keadaan, sedangkan kalimat 3) menunjukkan batasan "hanya" atau "selain itu tak ada". Bagi pembelajar bahasa Jepang tentu sulit untuk membeda-kan serta mengetahui perbandingan fungsi dan maknanya. Hal inilah yang menjadi pendorong dilakukannya penelitian tentang perbandingan fungsi dan makna partikel sae, shika, dan dake. Sebagai sumber data dalam penelitian ini, digunakan kalimat-kalimat yang mengandung partikel sae, shika, dan dake dalam novel Botchan karya Natsume Soseki.

\section{Rumusan Masalah}

Berdasarkan latar belakang tersebut, maka permasalahan yang selanjutnya dibahas dalam penelitian ini adalah sebagai berikut :

a. Bagaimanakah struktur, partikel sae, shika, dan dake dalam novel Botchan karya Natsume Soseki? 
b. Bagaimanakah fungsi partikel sae, shika, dan dake dalam novel Botchan karya Natsume Soseki?

c. Bagaimanakah makna Partikel sae, shika, dan dake dalam novel Botchan karya Natsume Soseki?

\section{Tujuan Penelitian}

Tujuan dari penelitian ini adalah untuk mengetahui struktur, fungsi dan makna partikel sae, shika, dan dake dalam novel Botchan karya Natsume Soseki.

\section{Metode Penelitian}

Metode dan teknik pengumpulan data yang dugunakan dalam penelitian ini adalah metode simak dengan teknik catat. Metode agih dengan teknik bagi unsur langsung merupakan metode dan teknik yang diguna-kan dalam penganalisisan data. Penyajian hasil analisis menggunakan metode formal dan informal. Teori yang digunakan dalam penelitian ini adalah teori sintaksis yang dikemukakan oleh Nitta (1991), teori fungsi dari Sunagawa (2000) dan teori makna kontekstual dari Chaer (2007).

\section{Hasil dan Pembahasan}

Setiap partikel dalam bahasa Jepang memiliki struktur pembentukan yang berbeda karena partikel tersebut digunakan pada waktu, tempat, dan situasi berdasarkan dengan konteks kalimat, sehingga akan menghasilkan fungsi dan makna yang sesuai dengan konteks kalimat tersebut. Tidak terkecuali juga ketika menyusun sebuah kalimat dengan menggunakan sebuah partikel terutama partikel sae, shika, dan dake. Setiap partikel tersebut memiliki peraturan-peraturan tersendiri mengenai cara pembentukan dengan kata yang diikuti maupun yang mengikuti partikel tersebut. Pertanyaan mengenai bentuk partikel sae, shika, dan dake akan dijelaskan pada bab ini.
Analisis data dilakukan dengan mengumpulkan seluruh kalimat yang menggunakan partikel sae, shika, dan dake pada novel Botchan karya Natsume Soseki. Selanjutnya, data yang ditemukan tersebut dikelompokkan berdasarkan fungsinya untuk kemudian dianalisis bentuk dan makna yang terkandung didalamnya yang menurut Sunagawa (2002), setiap partikel mempunyai bentuk, fungsi, dan makna lebih dari satu..

Partikel sae, shika, dan dake yang telah ditemukan dalan novel Botchan karya Natsume Soseki berjumlah 85 buah. Data tersebut terdiri dari 26 buah data dengan menggunakan partikel sae, empat buah data dengan menggunakan partikel shika, dan 54 buah data dengan menggunakan partikel dake.

\subsection{Struktur, Fungsi, dan Makna Partikel Sae \\ Mengacu dengan teori yang} dipergunakan dalam penelitian ini, berdasarkan struktur, fungsi, dan makna, maka analisis partikel sae sebagai berikut.

\subsubsection{Mempertegas Suatu Bagian}

Ketika partikel sae mengikuti $\mathrm{KB}$ atau INT dengan mo pada bagian belakang yang bersifat optional, maka sae berfungsi untuk mempertegas suatu bagian seperti pada fungsi partikel $g a$ dan $o$. Sae pada fungsi ini memiliki makna 'bahkan'. Terdapat dua buah struktur pembentukan kalimat dengan partikel sae pada bagian pertama ini, dan kedua bentuk ini dapat ditambahkan dengan partikel mo yang bersifat opsional. Dengan pola KB (+ PAR) sae (mo) dan INT ...ka sae (mo).

Ditemukan 10 buah data yang menggunakan pola kalimat ini dengan makna 'bahkan' pada novel Botchan karya Natsume Soseki.
(1)

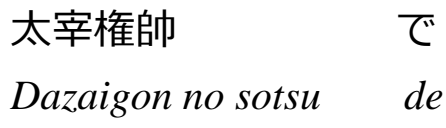


Pejabat pemerintahan PAR

さえ 博多
sae Hakata
bahkan nama tempat
近辺 で
kinpen de
lingkungan di
落ちついた もの だ。
ochitsuita mono da.
Jatuh-LAM benda KOP
"Bahkan pejabat pemerintahan
dulu pun diasingkan hingga Hakata"

(Natsume, 2001:87)

Pada data (1) tersebut, sae mengikuti $\mathrm{KB}$ daizagon no sotzu dan disisipi dengan partikel de. Partikel (de) sae pada data (1) memiliki makna 'bahkan' yang berfungsi untuk menegaskan bahwa pada zaman dahulu seorang pejabat pemerintahan dapat diasingkan ke suatu tempat. Kesan yang ditimbulkan adalah seseorang yang berkedudukan tinggi saja dapat dihukum sama halnya dengan orang biasa.

\subsubsection{Menunjukkan Suatu Syarat}

Ketika sae diikuti oleh KK POT taral $b a$, maka akan berfungsi untuk menunjukkan apabila ada salah satu syarat, semuanya akan tercakupi. Dalam hal ini, sae dapat diartikan sebagai 'asalkan ..., maka ...' dengan pola ...sae ...tara / ...ba .

Ditemukan 13 buah data yang menggunakan pola kalimat ini dengan makna 'asalkan..., maka...' pada novel Botchan karya Natsume Soseki.

(2) おれ が 何か 云い

Ore ga nanika ii

Aku NOM sesuatu berkata さえ

\section{すれば＼cjkstart笑う。}

bahkan melakukan-jika tertawa

"Apapun yang aku katakana, (dia/mereka) tertawa."
(Natsume, 2001:63)

Pada data (2), KKBB ii menjadi KKBB sebelum sae. Ii sendiri berasal dari iimasu yang dihilangkan akhiran masu sehingga hanya menjadi $i i$ yang berarti 'berkata', kemudian diikuti dengan KK bentuk pengandaian sureba setelah sae. Sae pada data ini menunjukkan suatu syarat, dan yang menunjukkan syarat tersebut adalah ore ga nani $k a$ ii 'apapun yang aku bicarakan', dengan hasilnya adalah warau 'tertawa'. Sae pada data ini bermakna 'asalkan', pembicara menyatakan bahwa bahkan asalkan dia berkata apapun juga, lawan bicaranya akan menjadi tertawa.

\subsubsection{Menunjukkan Suatu Tanpa Syarat}

Fungsi sae yaitu memiliki arti seperti pada fungsi demo 'meskipun' atau 'sekali-pun' dengan bentuk ...de sae. Pemakaian dengan makna ini hampir sama dengan de mo namun lebih bersifat menegaskan $\mathrm{KB}$ yang diikutinya.

Ditemukan 3 buah data yang menggunakan pola kalimat ini dengan makna 'meskipun' pada novel Botchan karya Natsume Soseki.

(3) 蔭口ををく の

Kageguchi wo kiku no

Belakang Ak mendengar GEN

\section{でさえ}

de sae

meskipun

"Meskipun dia membicarakan orang di belakang"

Pada data (3) di atas ini juga menggunakan de sae dengan makna 'meskipun'.

\subsection{Struktur, Fungsi, dan Makna Partikel Shika \\ Pembentukan kalimat dengan partikel shika harus diikuti oleh bentuk}


negatif. Meskipun harus diikuti oleh bentuk negatif, shika tidak bisa diartikan sebagai kalimat negatif begitu saja. Ditemukan 5 buah data yang menggunakan partikel shika pada novel Botchan karya Natsume Soseki.

Bahwasannya partikel shika dapat disusun dengan mengikuti sebuah $\mathrm{KB}$ dengan sebuah predikat berbentuk nai atau KB shika ...nai, juga dapat disisipi dengan sebuah partikel lainnya seperti $d e$, to, dan sebagainya atau KB (PAR) shika nai, dan sebuah kata kerja bentuk kamus (KKBB) yang langsung diikuti dengan shika nai atau KKBB shika nai.

\subsubsection{Menunjukkan Jumlah Terkecil}

Shika yang terletak setelah KB menunjukkan bahwa tidak ada yang lain kecuali jumlah tertentu dengan menyebutkan jumlah terkecil atau ketidakpuasan. Dalam hal ini, shika dapat berarti 'hanya', 'hanya satusatunya', 'kecuali', dan 'kecuali hanya'. Polanya adalah KB shika ...nai.

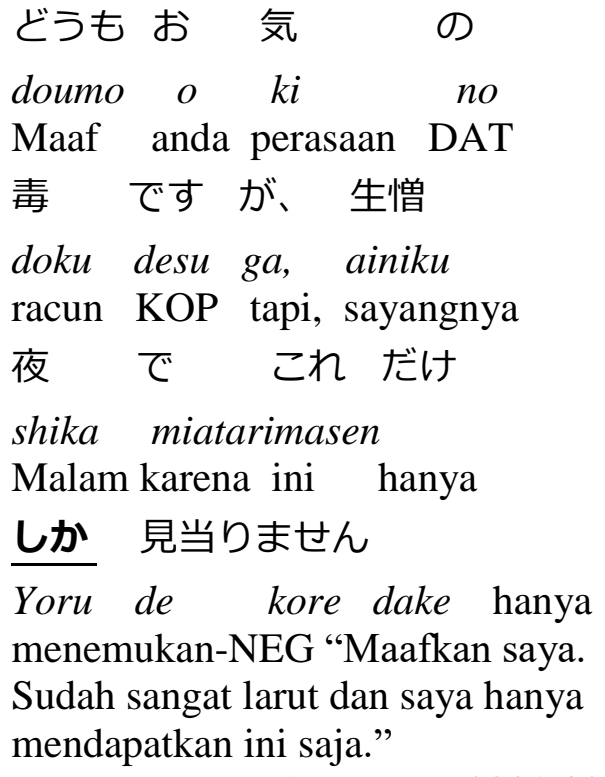

(Natsume, 2001:32)

Shika pada data (4) di atas, mengikuti kata ganti penunjuk benda kore 'yang ini', dan diikuti oleh bentuk negatif miatarimasen '(tidak) mendapatkan'.
Penggunaan dake sebelum shika pada kalimat ini bertujuan untuk lebih menekan-kan makna shika itu sendiri.

\subsubsection{Menunjukkan Batasan Perbuatan}

Ketika shika mengikuti KK BK, shika berfungsi untuk menunjukkan batas suatu perbuatan yang ditetapkan oleh KB tersebut. Dalam hal ini, shika memiliki arti 'mau tidak mau (harus melakukan)...' dengan pola KK BK shika nai. Tidak ditemukan satu pun data partikel shika yang memiliki fungsi dan makna ini pada novel Botchan karya Natsume Soseki.

\subsubsection{Menekankan Satu Hal Saja}

Ketika shika mengikuti P.KOM to, maka shika berfungsi untuk menekankan bahwa 'hanya dengan dan untuk (hal) ini saja, tidak dengan dan untuk (yang) lainnya' dengan pola ...to shika ...nai. Ditemukan sebuah data yang menggunakan pola kalimat ini dengan fungsi untuk menyatakan 'hanya dengan dan untuk (hal) ini saja, tidak dengan dan untuk (yang) lainnya' pada novel Botchan karya Natsume Soseki.

\begin{tabular}{|c|c|c|}
\hline 不都合 & と & しか \\
\hline Futsugou & to & shika \\
\hline Kerugian & P.KOM & hanya \\
\hline 思われな & & 事件 に \\
\hline$n$ & & jiken \\
\hline
\end{tabular}

berpikir-PAS-NEG kasus pada 会

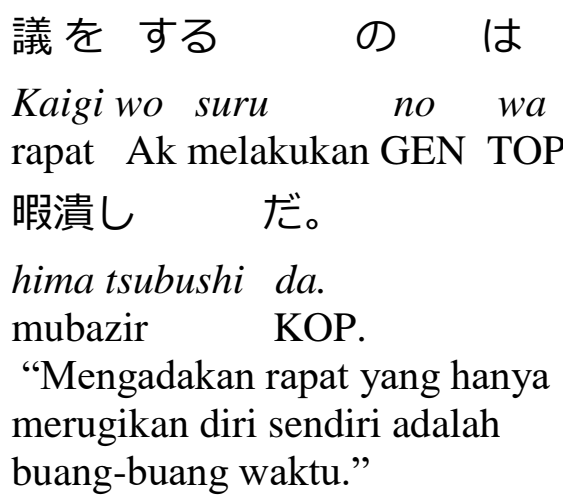

(Natsume, 2001:56) 
Shika dengan fungsi tersebut dapat ditemukan seperti pada data (5). ...to shika mengikuti KB futsugou 'kerugian', selanjutnya diikuti oleh bentuk negatif omowarenai '(tidak) terpikirkan'. Pembicara berpikir bahwa suatu hal yang dilakukan hanya menimbulkan kerugian saja. Dapat diartikan bahwa 'hanya dengan memikir-kannya saja sudah dapat dilihat bahwa hal tersebut merugikan'.

\subsection{Struktur, Fungsi, dan Makna Partikel Dake}

Terdapat 4 struktur pembentukan dengan partikel sae. Bentuk ini pada dasarnya terdiri dari partikel dake dan KOP desu (da). Dengan adanya KOP da setelah dake, dapat diartikan bahwa partikel dake pada bentuk ini berada di belakang kalimat.

\subsubsection{Menunjukkan Batasan}

\section{a. ... dake da}

Menunjukkan arti batasan, berarti 'hanya' atau 'selain itu tidak ada'. Dake dengan fungsi ini mengikuti $\mathrm{KB}$, $\mathrm{KSi} / \mathrm{KSna}$ ataupun KK dengan bentuk ...dake da.

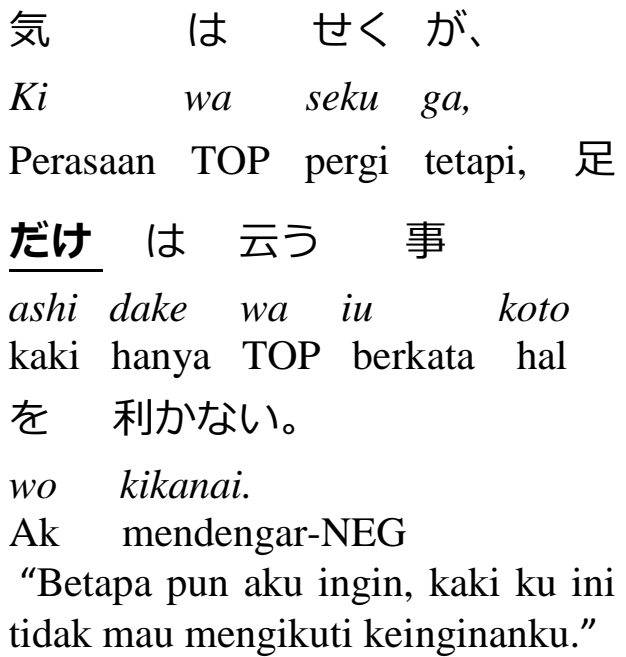

(Natsume, 2001:36)

Pada data (6) di atas, dake mengikuti KB ashi 'kaki' sehingga dapat berarti 'hanya kaki saja'. Hal ini sesuai dengan fungsi dake yaitu untuk menyatakan batasan. Batasan yang dimaksud pada data (6) tersebut adalah hanya kaki pembicara saja yang tidak mau mengikuti pikirannya, sedangkan bagian tubuh yang lain bergerak sesuai dengan keinginan pembicara.

b. ...dake shika ...nai

(7) どうも お 気 の

doumo o $\mathrm{ki}$ no

Maaf anda perasaan DAT

毒 です が、生憎

doku desu ga, ainiku

racun KOP tapi, sayangnya

夜 で これ だけ

shika miatarimasen

Malam karena ini hanya

しか 見当りません

Yoru de kore dake hanya menemukan-NEG "Maafkan saya. Sudah sangat larut dan saya hanya mendapatkan ini saja."

(Natsume, 2001:32)

Dake shika pada data (7) di atas mengikuti kata ganti penunjuk benda kore 'ini' yang berarti bahwa kore dibatasi oleh dake dan ditekankan pembatasan tersebut dengan shika. Ketika diartikan, kore dake shika dapat diartikan sebagai 'hanya ini'. Sepintas sama saja dengan fungsi dake (da) pada subbab sebelumnya, namun terdapat nuansa penekanan yang disampaikan pembicara bahwa memang benar-benar hanya ada 'ini' saja.

\subsubsection{Menunjukkan Derajat}

\section{a. KK Pot dake}

KK Pot yang digunakan pada umumnya adalah dekiru 'dapat'/ 'bisa'. Dengan demikian dapat diartikan sebagai 'sebisa (mungkin)' atau 'sedapat (mungkin)'. Dari seluruh data dake, tidak ditemukan data yang memiliki fungsi jumlah terbanyak dan makna 'sebisa 
mungkin' pada novel Botchan karya Natsume Soseki.

\section{b. KK-tai dake}

Ungkapan ini dapat diartikan sebagai 'se-(banyak) yang (anda) ...'. KK -tai yang terletak di depan dake merupakan objek yang akan dijelaskan oleh pembicara. Dari seluruh data dake, tidak ditemukan data yang memiliki fungsi jumlah terbanyak dan makna 'se(banyak) yang (anda)...' pada novel Botchan karya Natsume Soseki.

\subsubsection{Menunjukkan Kebiasaan}

\section{a. KSNa na / KB / KSi / KK dake ni}

Menunjukkan ungkapan yang bersifat kebiasaan yang menggunakan nomina dalam kalimat bentuk -dake ni menunjukkan arti 'karena'. Dapat juga bermakna 'ternyata' apabila hasil yang dicapai tidak memenuhi harapan dan oleh karena itu pembicara mengecilkan hati.

(8)

$\begin{array}{llll}\text { 女 } & \text { のような } & \text { を声 } & \text { を } \\ \text { Onna } & \text { no you na } & \text { koe } & \text { wo } \\ \text { Wanita } & \text { seperti } & \text { suara } & \text { Ak } \\ \end{array}$

だけに

dasu dake ni

mengeluarkan karena

\begin{tabular}{lll} 
心配性な & 男 & \multicolumn{1}{l}{} \\
shimpaisei na & otoko & to \\
gugup & lelaki & P.Kom
\end{tabular}

える。

mieru.

terlihat

"Oleh karena suaranya yang

kewanitaan, membuatnya terdengar sangat gugup."

(Natsume, 2001:51)

Dake ni pada data (8) di atas, mengikuti sebuh KK dasu 'mengeluarkan' yang menerangkan sebuah $\mathrm{KB}$ onna no you na koe 'suara seperti perempuan'. Pada data ini, dake ni berfungsi untuk mengungkapkan kebiasaan seseorang laki-laki yang berbicara atau mengeluarkan suara seperti seorang perempuan. Dake ni pada data ini bermakna 'karena'.

\section{b. ...dake no koto wa aru}

Menunjukkan hasil yang baik pada suatu perbuatan atau pekerjaan, biasanya mengikuti bentuk LAM dengan bentuk ...dake no koto wa aru. Frasa ini dapat berarti 'tidak sia-sia' apabila hasil yang dicapai memenuhi suatu harapan karena itu sebagai hasil usaha yang berharga.

Dari seluruh data dake, tidak ditemukan data yang memiliki fungsi untuk menunjuk-kan hasil yang baik dalam suatu pekerjaan dengan makna 'tidak sia-sia' pada novel Botchan karya Natsume Soseki.

\section{c. ...dake atte}

Menunjukkan hasil yang merupakan sebab yang sudah sepantasnya terjadi dari suatu keadaan. Frasa ini dapat berarti 'sudah sepantasnya'. Date atte dapat mengikuti KK BB atau informal.

(9) 田舎だけあって

Inaka dake atte

Kampung sudah sepantasnya 秋

がきても、

aki ga kitemo,

musim gugur NOM datang-pun,

気長に暑いももんだ。

kichouni atsui mon da.

Sangat panas GEN KOP.

"Meski musim gugur sudah datang, sudah sepantasnya sebuah kampung akan masih panas."

(Natsume, 2001:29)

Dake atte pada data (9) mengikuti sebuah KB inaka 'kampung' kemudian diikuti dengan atsui 'panas', dapat berarti 'sebuah kampung sudah sepantasnya 
panas'. Menurut pembicara, 'panas' sudah seharusnya dirasakan jika berada di sebuah 'kampung' meskipun sudah mulai berganti ke musim gugur.

\subsubsection{Menunjukkan Penegasan Suatu yang Lain}

a. KB (1) dake dewa naku KB (2)

Menunjukkan bukan hanya KB (1) saja yang dperhitungkan, KB (2) juga demikian. Dengan demikian kedudukan KB (1) dan KB (2) adalah sama. Ungkapan ini berarti 'bukan hanya $\mathrm{KB}$ (1), KB (2) juga ...'.

$\begin{array}{lccc}\text { (10) ハイカラ } & \text { 野郎 } & \text { だけ } & \text { では } \\ \text { Haikara } & \text { yarou dake } & \text { dewa } \\ \text { Pesolek } & \text { KOP } & \text { hanya } & \\ \text { 不足 } & \text { だ } & \text { よ } \\ \text { Fusoku } & & d a & \text { yo }\end{array}$
bukan kekurangan KOP SHU

"Dia bukan hanya seorang pesolek, tapi kurang dari itu."

(Natsume, 2001:97)

KB (1) adalah haikara 'pesolek', sedangkan KB (2) adalah fusoku 'kekurangan'. Dengan kata lain, data (10) di atas menunjukkan bukan hanya 'pesolek' saja, namun juga 'kurang dari itu. Kata 'pesolek' dipertegas kembali dengan adanya kata 'kekurangan'.

\section{Simpulan}

Berdasarkan hasil penelitian mengenai analisis penggunaan partikel sae, shika, dan dake dalam novel Botchan karya Natsume Soseki, dapat disimpulkan beberapa hal sesuai dengan permasalahan yang dibahas pada penelitian ini. Simpulan pada penelitian ini adalah partikel sae terdiri dari dua bentuk utama, bentuk partikel shika terdiri dari tiga bentuk, sedangkan bentuk partikel dake terdiri dari empat buah. Fungsi dan makna partikel sae adalah untuk mempertegas suatu bagian, menunjukkan syarat, dan menunjukkan tanpa syarat. Fungsi dan makna partikel shika adalah untuk menunjukikan jumlah terkecil, menunjukkan batasan perbuatan, dan menekankan satu hal saja. Fungsi dan makna partikel dake adalah menunjukkan batasan, tingkatan, kebiasaan, dan penegasan suatu yang lain.

\section{Daftar Pustaka}

Chaer, Abdul. 2007. Linguistik Umum. Jakarta : Rineka Cipta

Natsume, Soseki. 2001. Botchan. Tokyo : Koudansha LTD.

Nitta, Yoshio. 1991. Boisu no Kategorii to Bunkouzou no Reberu, dalam: Nitta Yoshio (ed.). Nihongo no Boisu to Tadousei. Tokyo: Kuroshio Shuppan.

Sudjianto,2000. Gramatika Bahasa Jepang Modern. Jakarta : Kesaint Blanc

Sudjianto dan A. Dahidi. 2007. Pengantar Linguistik Bahasa Jepang. Jakarta : Kesaint Blanc

Sugihartono, 2001. Partikel Bahasa Jepang. Bandung : Humaniora Utama Press

Sunagawa, Yoriko. 2002. Nihongo Bunkei Jiten. Tokyo: Kurosio. 